\title{
Kecanggihan Teknologi Informasi, Kompetensi Sumber Daya Manusia dan Efektivitas Penggunaan Sistem Keuangan Desa
}

\section{Ni Putu Sundari Maheni Premaswari ${ }^{1}$ \\ Fakultas Ekonomi dan Bisnis Universitas Udayana, Indonesia}

\author{
I Wayan Suartana ${ }^{2}$ \\ Fakultas Ekonomi dan Bisnis \\ Universitas Udayana, Indonesia
}

\begin{abstract}
Surel : sundarimaheni@gmail.com
ABSTRAK

Efektivitas penggunaan sistem keuangan desa perlu didukung oleh kompetensi sumber daya manusia yang baik dan teknologi informasi yang canggih. Penelitian bertujuan untuk mengetahui bagaimana pengaruh kecanggihan teknologi informasi dan kompetensi sumber daya manusia terhadap efektivitas penggunaan sistem keuangan desa (Siskeudes) pada Pemerintahan Desa di Kota Denpasar. Penelitian ini dilakukan pada Pemerintahan Desa di Kota Denpasar dengan teknik sampling jenuh yang menggunakan 54 sampel. Pengumpulan data dilakukan melalui wawancara dan penyebaran kuesioner. Teknik analisis yang digunakan dalam penelitian ini adalah analisis regresi linier berganda. Hasil penelitian ini menunjukkan bahwa semakin canggih teknologi informasi dan semakin bagus kompetensi sumber daya manusia maka semakin efektif penggunaan siskeudes.
\end{abstract}

Kata Kunci: Kecanggihan Teknologi Informasi; Kompetensi Sumber Daya Manusia; Efektivitas Penggunaan Sistem Keuangan Desa.

\section{Sophistication of Information Technology, Competence of Human Resources and Effective Use of the Village Financial System}

\section{ABSTRACT}

The effectiveness of the use of the village financial system needs to be supported by the competence of good human resources and sophisticated information technology. This study aims to determine how the influence of information technology sophistication and human resource competence on the effectiveness of the use of the village financial system (Siskeudes) in the Village Government in Denpasar City. This research was conducted at the Village Government in Denpasar City with a saturated sampling technique using 54 samples. Data collection was carried out through interviews and questionnaires. The analysis technique used in this research is multiple linear regression analysis. The results of this study indicate that the more sophisticated the information technology and the better the competence of human resources, using the village financial system will be more effective.

Keywords: Sophistication of information Technology; Human Resource Competence; Effectiveness of Using The Village Financial System.

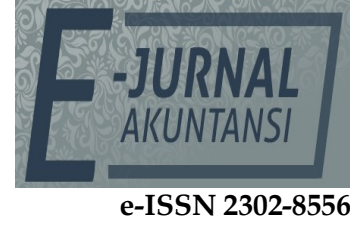

Vol. 31 No. 8

Denpasar, Agustus 2021

Hal. 1987-1998

DOI:

10.24843/EJA.2021.v31.i08.p09

PENGUTIPAN:

Premaswari, N.P.S.M., \& Suartana, I.W. (2021).

Kecanggihan Teknologi Informasi, Kompetensi Sumber Daya Manusia dan Efektivitas Penggunaan

Sistem Keuangan Desa. EJurnal Akuntansi, 31(8), 1987-

1998

RIWAYAT ARTIKEL: Artikel Masuk: 18 Januari 2021 Artikel Diterima: 29 Maret 2021

Artikel dapat diakses : https://ojs.unud.ac.id/index.php/Akuntansi/index 


\section{PENDAHULUAN}

Komitmen politik bahwa Negara telah memperhatikan dan melindungi posisi desa ditegaskan dalam Undang-Undang Nomor 6 Tahun 2014 yaitu mewujudkan cita-cita kesejahteraan, tatanan yang lebih kuat dan demokratis dalam pemerintahan serta menciptakan masyarakat yang adil, makmur dan sejahtera (Dinas Pemberdayaan Masyarakat \& Desa Provinsi Bali, 2017:1). Pratiwi \& Pravasanti (2020) menerangkan bahwa untuk mendukung pelaksanaan tugas dan fungsi Desa, pemerintah mengalokasikan dana desa yang bersumber dari APBN (Anggaran Pendapatan Belanja Negara) serta merancang peraturan tentang pengelolaan dana desa untuk meningkatkan efisiensi, efektivitas, transparansi, dan akuntabilitas pemanfaatan dana desa.

Alokasi dana desa bersumber dari APBD yang dianggarkan minimal sebesar 10 persen dari Dana Alokasi Umum (DAU) ditambah Dana Bagi Hasil (DBH), sedangkan dana desa bersumber dari APBN. Berdasarkan Pasal 24 UndangUndang Nomor 6 Tahun 2014, penyelenggaraan pemerintahan desa didasari atas asas akuntabilitas serta asas efektivitas dan efisien. Alokasi dana desa tersebut kemudian akan dikelola oleh aparatur Pemerintah Desa sesuai APBDes yang didapatkan dan diawasi melalui sistem yang dikembangkan oleh Badan Pengawasan Keuangan dan Pembangunan (BPKP).

Berdasarkan regional.kompas.com (Gamar, 2019) diakses pada 5 April 2020, terdapat salah satu kasus penyelewengan dana desa yang terjadi di Desa Dauh Puri Klod di Kota Denpasar dugaan penyelewengan timbul ketika selisihnya antara SILPA dengan dana yang masih dipegang sebesar Rp 1,035 miliar, tidak jelas keberadaannya. Sebagai upaya untuk mengantisipasi terjadinya permasalahan dalam mengelola APBDesa dan mendukung peraturan pengelolaan keuangan desa yang transparan, akuntabel, serta partisipatif pemerintah mengembangkan sebuah sistem informasi akuntansi yaitu Siskeudes.

Siskeudes merupakan salah satu bentuk pembenahan dalam mengelola laporan keuangan serta pertanggungjawaban dana desa menjadi lebih efektif, efisien, dan tranparansi. Pemerintah Kota Denpasar telah mengadopsi serta menerapkan konsep Smart City dalam melakukan pelayanan kepada masyarakat. Konsep kota cerdas (Smart City) dicerminkan dalam setiap kegiatan pemerintahan salah satunya pengambilan langkah untuk melakukan penerapan Siskeudes dalam pengelolaan dana desa pada seluruh desa di Kota Denpasar.

Seiring pesatnya perkembangan teknologi informasi pada era revolusi industri 4.0 dimana teknologi informasi dan komunikasi dimanfaatkan sepenuhnya guna mencapai efisiensi. Pradani et al. (2017) mengemukakan bahwa kecanggihan perangkat yang digunakan dalam teknologi komputer sangat berpengaruh dalam mendukung efektivitas dan kinerja sistem informasi akuntansi dengan memperhatikan seberapa canggih teknologi yang dibutuhkan. Kecanggihan perangkat hardware dan software dalam teknologi komputer sangat berpengaruh terhadap efektivitas penggunaan Siskeudes. Hal ini sejalan dengan penelitian yang dilakukan Lisnawati et al. (2017) yang mengemukakan bahwa kecanggihan teknologi informasi berpengaruh positif dan signifikan terhadap sistem informasi akuntansi.

Perencanaan sistem dengan memperhatikan faktor sumber daya manusia sebagai pengguna sistem sangat penting untuk mendukung teknologi sehingga 
dapat mempercepat proses adaptasi dalam penggunaan teknologi. Teknologi yang praktis, sederhana, dan mudah digunakan akan lebih mudah diadaptasi oleh pengguna (Shanab \& Haider, 2015). Pemanfaatan teknologi informasi yang baik diharapkan dapat menghasilkan informasi yang lebih bermutu apabila sumber daya manusia yang terlibat dalam proses implementasi sistem keuangan desa juga berkualitas (Puspita, 2018). Tanpa pertimbangan faktor sumber daya manusia, secanggih apapun sistem informasi yang dirancang tidak akan berjalan dengan baik tanpa ditunjang dengan sumber daya manusia yang cakap dan profesional. Keberhasilan penerapan operasi sistem teknologi informasi yang lebih canggih di dalam suatu lingkungan baru tergantung pada kepercayaan penuh para pengguna (Coutu, 1998). Kesalahan memasukan data, kurangnya pengetahuan, kurangnya pengalaman pengguna juga menghambat sistem informasi akuntansi. Hal ini karena operasional teknologi informasi masih menggunakan faktor manusia. Hal ini sejalan dengan penelitian yang dilakukan oleh Paranoan et al. (2019) yaitu kompetensi sumber daya manusia berpengaruh positif dan siginifikan terhadap efektivitas sistem informasi akuntansi. Topik penelitian akan dijelaskan dan dihubungkan menggunakan kerangka konseptual sebagai berikut.

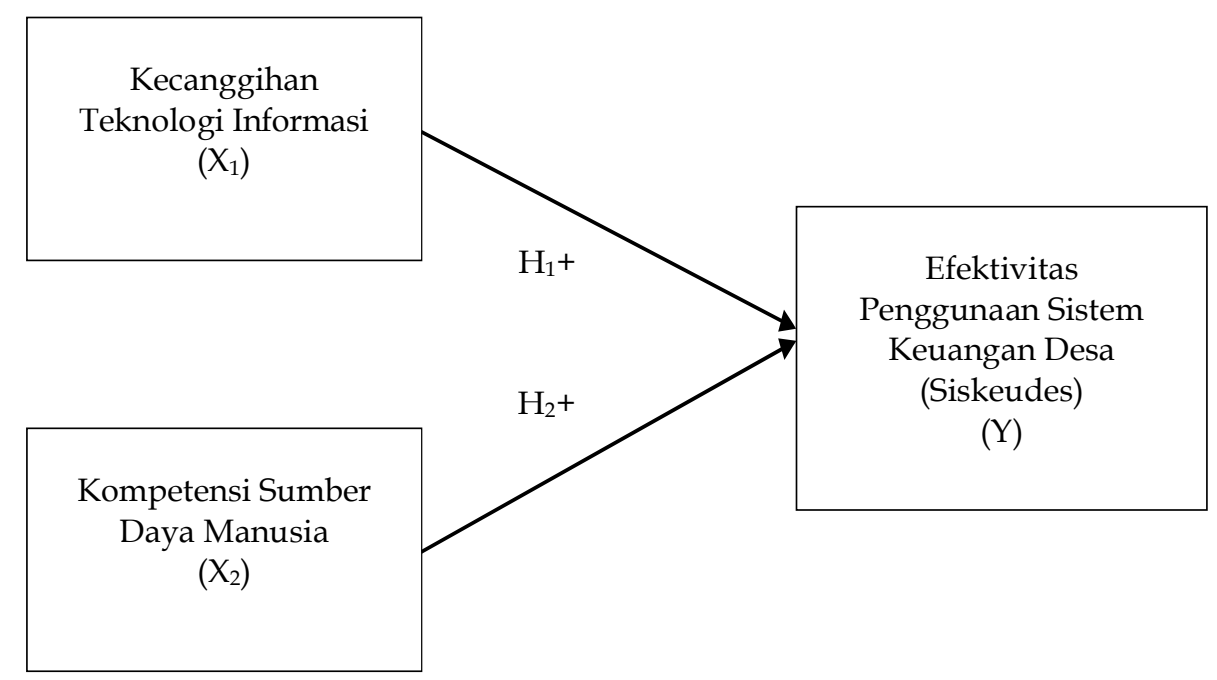

Gambar 1. Model Penelitian

Sumber: Data Penelitian, 2021

Ajzen \& M. Fishbein (1980) mengemukakan bahwa TAM (Theory Acceptance Model) didasari oleh Theory of Reasoned Action (TRA). Tujuan utama theory acceptance model ialah memberikan penjelasan tentang penentuan penerimaan teknologi informasi secara umum serta memberikan penjelasan tentang perilaku atau sikap pengguna dalam suatu organisasi (Davis, 1989). Teori ini menyebutkan bahwa tingkah laku pengguna merupakan hasil dari penggunaan teknologi informasi yang Perceived Usefulness dan Perceived Ease of Use, dan hubungan sebab akibat dari kedua hal ini akan mendapatkan hasil yang diharapkan penggunaan teknologi (King \& He, 2006). Kedua variabel ini memiliki pengaruh langsung dalam sikap terhadap penggunaan teknologi, dan menurut Fishbein \& Ajzen (1975), sikap adalah kecenderungan yang dipelajari untuk menjawab baik atau tidak baik sehubungan dengan objek tertentu. Dianggap bahwa sikap adalah hasil 
dari keyakinan subjek mengenai perilaku dan hasil-hasilnya, dan pentingnya diberikan keyakinan tersebut (Wagner et al. 2013).

Perkembangan yang semakin pesat dalam pengembangan sistem informasi akuntansi seperti Siskeudes sebelumnya belum terintegrasi secara online dengan pemerintah daerah lalu dikembangkan menjadi terintegrasi secara online. Perkembangan ini perlu adanya dukungan teknologi informasi yang lebih canggih berupa perangkat keras atau komputer dan perangkat lunak atau software pendukung. Tanpa dukungan teknologi informasi yang canggih, sistem keuangan desa tidak dapat digunakan secara lebih efektif dan optimal.

Berdasarkan Putri \& Srinadi (2020), kecanggihan teknologi informasi berpengaruh positif dan signifikan terhadap efektivitas penggunaan sistem informasi akuntansi di LPD Kecamatan Ubud. Begitu juga dengan penelitian yang dilakukan oleh Utari et al. (2017) dan Lisnawati et al. (2017) yang menemukan bahwa kecanggihan teknologi informasi berpengaruh positif dan signifikan terhadap efektivitas sistem informasi akuntansi. Sehingga hipotesis penelitian yang pertama.

$\mathrm{H}_{1}$ : Kecanggihan Teknologi Informasi berpengaruh positif terhadap Efektivitas Penggunaan Sistem Keuangan Desa (Siskeudes).

Kemampuan teknis pengguna sistem informasi sangat bermanfaat dan berperan penting dalam pengembangan sistem informasi untuk dapat menghasilkan informasi guna menciptakan laporan perencanaan yang akurat dan dapat dipercaya. Berdasarkan penelitian yang dilakukan oleh Nintyari et al. (2019), Paranoan et al. (2019) dan Prasetya et al. (2017) kompetensi sumber daya manusia berpengaruh positif dan signifikan terhadap efektivitas dan efisiensi pelaksanaan Siskeudes. Sehingga hipotesis penelitian yang kedua.

$\mathrm{H}_{2}$ : Kompetensi Sumber Daya Manusia berpengaruh positif terhadap Efektivitas Penggunaan Sistem Keuangan Desa (Siskeudes).

\section{METODE PENELITIAN}

Penelitian ini merupakan penelitian asosiatif dengan menggunakan pendekatan kuantitatif. Tujuan dari penelitian ini adalah untuk mengetahui bagaimana pengaruh kecanggihan teknologi informasi dan kompetensi sumber daya manusia terhadap efektivitas penggunaan sistem keuangan desa (Siskeudes) pada Pemerintahan Desa di Kota Denpasar. Penelitian ini dilakukan pada Pemerintahan Desa yang terdapat di Kota Denpasar. Peneliti tertarik melakukan penelitian pada Pemerintahan Desa yang terdapat di Kota Denpasar dikarenakan Kota Denpasar merupakan ibukota Provinsi Bali, Kota Denpasar dinobatkan sebagai kota paling makmur di Indonesia dengan skor 60,2 persen dengan katagori moderately solid dan adanya kasus penyelewengan dana desa yang terjadi di Desa Dauh Puri Klod di Kota Denpasar.

Objek penelitian yang digunakan yaitu kecanggihan teknologi informasi, kompetensi sumber daya manusia dan efektivitas penggunaan Sistem Keuangan Desa (Siskeudes). Penelitian ini terdiri dari variabel dependen yaitu efektivitas penggunaan Sistem Keuangan Desa (Siskeudes) (Y), serta variabel independen yakni kecanggihan teknologi informasi $\left(X_{1}\right)$ dan kompetensi sumber daya manusia $\left(\mathrm{X}_{2}\right)$. 
Kecanggihan teknologi informasi adalah perkembangan modernisasi teknologi informasi yang salah satunya dapat dilihat pada teknologi terkomputerisasi dalam pengelolaan sistem informasi akuntansi, melalui perangkat lunak dan perangkat keras sebuah teknologi yang terkomputerisasi dapat dinilai seberapa canggih teknologi tersebut. Variabel kecanggihan teknologi informasi diukur dengan mengadopsi kuesioner yang mengacu pada penelitian Thompson et al (1991) dalam Rahmawati (2012) dilihat dari faktor sosial, faktor affect dan konsekuensi jangka panjang.

Kompetensi sumber daya manusia yang dimaksud disini merupakan pengetahuan, kemampuan dan keahlian yang dimiliki oleh aparatur desa dalam kaitannya dengan penggunaan Sistem Keuangan Desa (Siskeudes). Variabel kompetensi sumber daya manusia diukur dengan mengadopsi kuesioner yang terdiri dari 8 pernyataan dari penelitian Yunianingrum \& Kolopaking (2018) dengan indikator, yaitu: kemampuan, pelatihan, keterampilan dan kerjasama.

Penggunaan sistem informasi akuntansi dapat dikatakan efektif apabila dapat menghasilkan laporan keuangan diterima dengan tepat, akurat, relevan, memiliki fitur lengkap sehingga memudahkan pengguna dan dapat dipercaya sehingga dapat digunakan sebagai dasar dalam pengambilan keputusan. Variabel efektivitas penggunaan sistem keuangan desa diukur dengan menggunakan instrumen dari indikator Jumaili (2005) dalam Miati \& Sutapa (2019) yaitu efektivitas sistem informasi akuntansi merupakan sistem informasi yang menyediakan informasi tepat waktu, relevan, lengkap, akurat untuk penyelesaian tugas serta menghasilkan informasi untuk pertanggungjawaban dan mendukung dalam pengambilan keputusan.

Populasi pada penelitian ini adalah Bendahara Desa dan Staff yang menangani aplikasi Siskeudes pada seluruh desa di Kota Denpasar. Metode penentuan sampel yang digunakan dalam penelitian ini adalah non probability sampling dengan teknik sampling jenuh, sehingga jumlah sampel sama dengan populasi, yaitu 54 sampel. Metode pengumpulan data yang digunakan dalam penelitian ini adalah observasi dan kuesioner.

Data yang telah terkumpul akan dianalisis dengan analisis deskriptif. Kelayakan model regresi pada penelitian ini akan diuji menggunakan uji asumsi klasik yaitu uji normalitas, uji multikolinearitas, dan heteroskedastisitas. Alat analisis yang digunakan untuk mengukur hubungan antara dua variabel atau lebih yaitu analisis regresi linier berganda. Besarnya kontribusi variabel dependen terhadap variabel dependen diketahui melalui pengujian koefisien determinasi $\left(R^{2}\right)$. Kelayakan model regresi yang digunakan harus diuji menggunakan uji $F$ untuk mengetahui apakah model tersebut layak digunakan untuk menguji pengaruh variabel dependen pada independen. Pengujian hipotesis dalam penelitian ini menggunakan uji $t$ (t-test). Rumus model regresi linier berganda yang digunakan adalah sebagai berikut.

$$
Y=\alpha+\beta_{1} X_{1}+\beta_{2} X_{2}+\varepsilon
$$

Keterangan:

$Y=$ Efektivitas Penggunaan Sistem Keuangan Desa (Siskeudes)

$\mathrm{X}_{1}=$ Kecanggihan Teknologi Informasi

$\mathrm{X}_{2}=$ Kompetensi Sumber Daya Manusia 


$$
\begin{aligned}
& a=\text { Konstanta } \\
& \beta_{1} \beta_{2}=\text { Koefisien regresi dari } X_{1}-X_{2} \\
& \varepsilon=\text { Standard Eror }
\end{aligned}
$$

\section{HASIL DAN PEMBAHASAN}

Berdasarkan hasil penelitian yang menggunakan metode penarikan sampel non probability sampling dengan teknik sampling jenuh maka didapatkan responden sebanyak 54 aparatur desa yang memiliki kemampuan mengoperasikan aplikasi sistem keuangan desa yang terdiri dari Bendahara Desa dan Staff yang menangani aplikasi Siskeudes pada setiap desa di Kota Denpasar. Karakteristik responden

\begin{tabular}{|c|c|c|c|c|}
\hline No & Variabel & Klasifikasi & $\begin{array}{l}\text { Jumlah } \\
\text { (Orang) }\end{array}$ & Persentase (\%) \\
\hline \multirow[t]{3}{*}{1} & Jenis Kelamin & Pria & 20 & 37,03 \\
\hline & & Wanita & 34 & 62,96 \\
\hline & Total & & 54 & 100,00 \\
\hline \multirow[t]{5}{*}{2} & Usia & 20-30 tahun & 24 & 44,44 \\
\hline & & 31-40 tahun & 16 & 29,62 \\
\hline & & 41-50 tahun & 12 & 22,22 \\
\hline & & $>50$ tahun & 2 & 3,72 \\
\hline & Total & & 54 & 100,00 \\
\hline \multirow[t]{4}{*}{3} & Pendidikan & D3 & 19 & 35,18 \\
\hline & Terakhir & D4 & 0 & 0,00 \\
\hline & & S1 & 35 & 64,82 \\
\hline & Total & & 54 & 100,00 \\
\hline
\end{tabular}
dilihat dari 3 dimensi, yaitu jenis kelamin, usia, dan pendidikan terakhir.

Tabel 1. Karakteristik Responden

Sumber: Data Penelitian, 2021

Berdasarkan Tabel 1, dapat dilihat karakteristik responden yang pertama adalah jenis kelamin, persentase responden wanita sebesar 62,96 persen dan responden pria sebesar 37,03 persen. Hal ini menunjukkan bahwa responden wanita lebih banyak dibandingkan pria.

Karakteristik kedua yaitu usia, usia dominan responden adalah pada usia 20-30 tahun dengan persentase 44,44 persen, sedangkan untuk kelompok usia yang terendah adalah pada usia $>50$ tahun dengan persentase 3,72 persen. Karakteristik ketiga adalah pendidikan terakhir yang didominasi oleh responden dengan pendidikan terakhir S1 dengan persentase 64,82 persen, sedangkan yang terendah adalah responden dengan pendidikan terakhir D3 dengan persentase 35,18 persen.

Kelayakan model regresi pada penelitian akan diuji menggunakan uji asumsi klasik yaitu uji normalitas, uji multikolinearitas, dan heteroskedastisitas. Uji normalitas dilakukan menggunakan statistik Kolmogorov-Smirnov, data yang digunakan akan dapat dinyatakan berdistribusi secara normal apabila koefisien Asymp.Sig (2-tailed) lebih besar dari 0,05 ( $\mathrm{a}=5$ persen). 
Tabel 2. Uji Normalitas

\begin{tabular}{llr}
\hline & One-Sample Kolmogorov-Smirnov Test & Unstandardized Residual \\
\hline $\mathrm{N}$ & & 56 \\
Normal Parameters ${ }^{a, b}$ & Mean & 0,000 \\
& Std. Deviation & 0,651 \\
Most Extreme Differences & Absolute & 0,081 \\
& Positive & 0,064 \\
& Negative & $-0,081$ \\
Test Statistic & & 0,081 \\
Asymp. Sig. (2-tailed) & $0,2000^{c, d}$ \\
a. Test distribution is Normal. & & \\
b. Calculated from data. & \\
c. Lilliefors Significance Correction. & \\
d. This is a lower bound of the true significance. & \\
\hline
\end{tabular}

Sumber: Data Penelitian, 2021

Berdasarkan hasil Tabel 2, didapatkan bahwa koefisien Asymp.Sig (2-tailed) sebesar 0,200 sedangkan tingkat signifikan yang digunakan adalah 0,05. Karena koefisien Asymp.Sig (2-tailed) lebih besar dari a maka dapat disimpulkan bahwa model struktur ini telah berdistribusi normal $(0,200>0,05)$. Hasil pengujian multikoleniaritas dapat diketahui dengan melihat dari tingkat tolerance apakah lebih besar dari 10 persen $(0,10)$ atau dapat juga dilihat dari nilai VIF.

Tabel 3. Uji Multikoleniaritas

\begin{tabular}{ccc}
\hline Variabel & Tolerance & VIF \\
\hline Kecanggihan TI & 0,380 & 2,634 \\
Kompetensi SDM & 0,380 & 2,634 \\
\hline
\end{tabular}

Sumber: Data Penelitian, 2021

Berdasarkan hasil Tabel 3, menunjukkan bahwa variabel kompensasi tidak bersifat multikolinearitas. Hal ini dapat dilihat dari tingkat tolerance variabel independen sebesar 0,380 dimana nilai tolerance lebih besar 0,10, dan nilai VIF sebesar 2,634<10,00. Hasil pengujian heteroskedastisitas dapat dilihat pada nilai signifikansi yang lebih besar dari 0,05, maka data tersebut dinyatakan tidak terdapat gejala homoskedastisitas.

Tabel 4. Uji Heteroskedastisitas

\begin{tabular}{|c|c|c|c|c|c|}
\hline \multirow[b]{2}{*}{ Model } & \multicolumn{2}{|c|}{$\begin{array}{c}\text { Unstandardized } \\
\text { Coefficients }\end{array}$} & \multirow{2}{*}{$\begin{array}{c}\text { Standardized } \\
\text { Coefficients }\end{array}$} & \multirow[b]{2}{*}{$\mathrm{t}$} & \multirow[b]{2}{*}{ Sig. } \\
\hline & $\mathrm{B}$ & Std. Error & & & \\
\hline $1 \quad$ (Constant) & 2,367 & 0,729 & & 3,244 & 0,002 \\
\hline Kecanggihan TI & $-0,002$ & 0,030 & $-0,011$ &,- 053 & 0,958 \\
\hline Kompetensi SDM & $-0,065$ & 0,039 & $-0,347$ & $-1,668$ & 0,101 \\
\hline
\end{tabular}

Sumber: Data penelitian, 2021

Pada Tabel 4, nilai signifkan variabel independen dalam penelitian ini bernilai 0,958 dan 0,101. Nilai signifikan variabel independen yang didapatkan < 0,05 sehingga dapat disimpulkan bahwa kedua variabel independen dalam penelitian ini tidak memiliki gejala heteroskedastisitas. Analisis regresi linier berganda digunakan untuk mengukur hubungan antara dua variabel atau lebih dan sebagai alat untuk menunjukkan adanya arah hubungan positif atau negatif antara variabel independen pada variabel dependen. 
Tabel 5. Hasil Analisis Regresi Linier Berganda

\begin{tabular}{lrrrrr}
\hline \multirow{2}{*}{ Model } & \multicolumn{2}{c}{$\begin{array}{l}\text { Unstandardized } \\
\text { Coefficients }\end{array}$} & $\begin{array}{c}\text { Standardized } \\
\text { Coefficients }\end{array}$ & & \multicolumn{2}{c}{ Sig. } \\
\cline { 2 - 5 } & \multicolumn{1}{c}{ B } & Std. Error & Beta & & \\
\hline (Constant) & $-3,016$ & 1,303 & & $-2,315$ & 0,025 \\
Kecanggihan TI & 0,248 & 0,054 & 0,434 & 4,573 & 0,000 \\
Kompetensi SDM & 0,382 & 0,070 & 0,522 & 5,502 & 0,000 \\
\hline
\end{tabular}

Sumber: Data Penelitian, 2021

Berdasarkan Tabel 5, rumus model regresi linier berganda yang digunakan adalah sebagai berikut.

$$
Y=-3,016+0,248 X_{1}+0,382 X_{2}+\varepsilon
$$

Keterangan:

$\mathrm{Y}=$ Efektivitas Penggunaan Sistem Keuangan Desa (Siskeudes)

$\mathrm{X}_{1} \quad=$ Kecanggihan Teknologi Informasi

$\mathrm{X}_{2} \quad=$ Kompetensi Sumber Daya Manusia

$\varepsilon \quad=$ Standard Eror

Besarnya kontribusi variabel dependen terhadap variabel dependen diketahui melalui pengujian koefisien determinasi $\left(R^{2}\right)$. Koefisien determinasi dapat dilihat melalui nilai adjusted $R^{2}$ antara 0 atau 1 . Nilai Adjusted $R$ Square yang kecil menunjukkan kemampuan variabel independen dalam menjelaskan variasi variabel dependen sangat terbatas. Nilai Adjusted $R$ Square mendekati 1 berarti variabel independen memberikan hampir semua informasi yang dibutuhkan dalam memprediksi variabel dependen.

Tabel 6. Uji Determinasi

\begin{tabular}{lrrrr}
\hline Model & $\mathrm{R}$ & $\mathrm{R}$ Square & \multicolumn{1}{c}{$\begin{array}{c}\text { Adjusted } R \\
\text { Square }\end{array}$} & Std. Error of the Estimate \\
\hline 1 & $0,905^{\mathrm{a}}$ & 0,819 & 0,812 & 0,663
\end{tabular}

a. Predictors: (Constant), Kompetensi SDM, Kecanggihan TI

b. Dependen Variable: Efektivitas Siskeudes Sumber: Data Penelitian, 2021

Pada Tabel 6, nilai R square dalam penelitian ini adalah 0,819 . Nilai R square tersebut dapat diartikan bahwa variabel kecanggihan teknologi informasi dan kompetensi sumber daya manusia dapat mempengaruhi efektivitas penggunaan sistem keuangan desa sebesar 81,9 persen. Sisanya 18,1 persen dipengaruhi oleh variabel lain diluar model yang digunakan. Kelayakan model regresi yang digunakan harus diuji menggunakan uji $\mathrm{F}$ untuk mengetahui apakah model tersebut layak digunakan untuk menguji pengaruh variabel dependen pada independen. Pengujian dilakukan dengan bantuan SPSS dengan mengamati significance level 0,05 ( $\alpha=5$ persen) tabel ANOVA. Untuk menguji hipotesis ini digunakan statistik F dengan kriteria pengambilan keputusan (Ghozali, 2016).

Bila nilai signifikansi ANOVA $<0,05$, maka $\mathrm{H}_{0}$ ditolak atau $\mathrm{H}_{1}$ diterima yang berarti koefisien regresi signifikan, artinya terdapat pengaruh yang signifikan antara semua variabel independen pada variabel dependen. Bila nilai signifikansi ANOVA $>0,05$, maka $\mathrm{H}_{0}$ diterima atau $\mathrm{H}_{1}$ ditolak yang berarti koefisien regresi tidak signifikan. Hal ini berarti semua variabel independen tidak terpengaruh pada variabel dependen. 
Tabel 7. Uji F

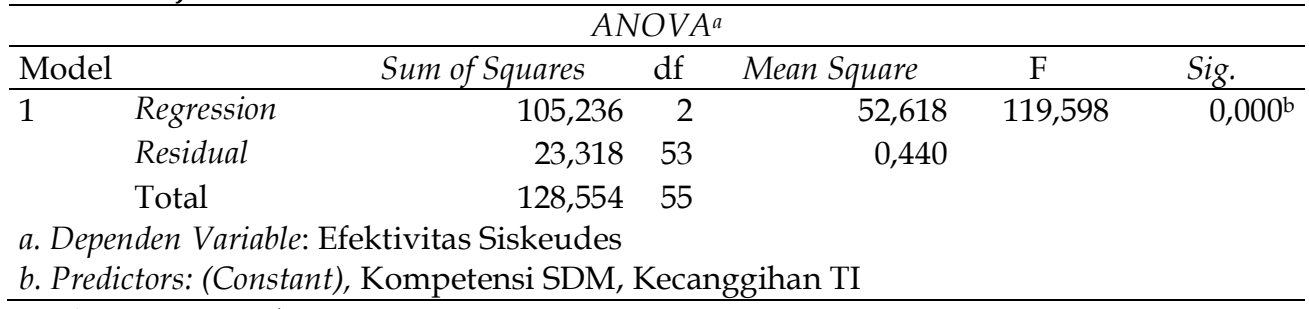

Sumber: Data penelitian, 2021

Berdasarkan Tabel 7, diketahui nilai uji F pada tabel sig adalah sebesar 0,000. Nilai sig 0,000 < 0,05 maka sebagaimana dasar pengambilan keputusan dalam uji F dapat disimpulkan bahwa variabel independen secara simultan (bersamasama) berpengaruh terhadap variabel dependen.

Pengujian hipotesis dalam penelitian ini menggunakan uji $t$ (t-test). Uji $t(t-$ test) digunakan untuk menunjukkan seberapa jauh pengaruh variabel independen secara individual dalam menerangkan variasi dari variabel dependen.

Tabel 8. Hasil Uji Hipotesis

\begin{tabular}{|c|c|c|c|c|c|}
\hline \multirow[t]{2}{*}{ Model } & \multicolumn{2}{|c|}{$\begin{array}{c}\text { Unstandardized } \\
\text { Coefficients }\end{array}$} & \multirow{2}{*}{$\begin{array}{c}\begin{array}{c}\text { Standardized } \\
\text { Coefficients }\end{array} \\
\text { Beta }\end{array}$} & \multirow[t]{2}{*}{$\mathrm{T}$} & \multirow[t]{2}{*}{ Sig. } \\
\hline & B & $\begin{array}{l}\text { Std. } \\
\text { Error }\end{array}$ & & & \\
\hline (Constant) & $-3,016$ & 1,303 & & $-2,315$ & 0,025 \\
\hline Kecanggihan TI & 0,248 & 0,054 & 0,434 & 4,573 & 0,000 \\
\hline Kompetensi SDM & 0,382 & 0,070 & 0,522 & 5,502 & 0,000 \\
\hline
\end{tabular}

Sumber: Data Penelitian, 2021

Pada hasil analisis regresi linier berganda pengaruh $\mathrm{X} 1$ terhadap $\mathrm{Y}, \mathrm{Nilai}$ sig t. $0,000 \leq 0,05$ mengindikasikan bahwa $\mathrm{H}_{0}$ ditolak dan $\mathrm{H}_{1}$ diterima yang berarti terdapat pengaruh kecanggihan teknologi informasi terhadap efektivitas penggunaan Sistem Keuangan Desa (Siskeudes). Nilai koefisien beta sebesar 0,248 menunjukkan arah positif. Hal ini berarti kecanggihan teknologi informasi memiliki pengaruh positif dan signifikan terhadap efektivitas penggunaan Sistem Keuangan Desa (Siskeudes) di Kota Denpasar, sehingga semakin canggih teknologi informasi maka penggunaan aplikasi sistem keuangan desa akan semakin efektif. Soudani (2012) menyatakan bahwa teknologi informasi yang canggih sangat dibutuhkan untuk meningkatkan efektivitas penggunaan sistem keuangan desa yang terintegrasi sehingga memudahkan dalam pengumpulan, penyimpanan, dan menghubungkan data yang digunakan dengan tujuan perencanaan, pengendalian, dan pengambilan keputusan. Pentingnya penggunaan sistem informasi dalam menghasilkan informasi yang berkualitas dan mendukung proses pengambilan keputusan dapat meningkatkan efisiensi organisasi (Nabizadeh \& Omrani, 2014). Sistem informasi akuntansi yang menghasilkan informasi berkualitas sangat berperan penting untuk meningkatkan citra dan memajukan instansi (Nwokeji, 2012). Hasil dari penelitian ini serupa dengan penelitian Putri \& Srinadi (2020), kecanggihan teknologi informasi berpengaruh positif dan signifikan terhadap efektivitas penggunaan sistem informasi akuntansi di LPD Kecamatan Ubud. Penelitian Utari et al. (2017) juga 
menemukan kecanggihan teknologi informasi berpengaruh positif dan signifikan terhadap efektivitas sistem informasi akuntansi. Begitu juga dengan penelitian yang dilakukan oleh Lisnawati et al. (2017) yang menemukan bahwa kecanggihan teknologi informasi berpengaruh positif dan signifikan terhadap efektivitas sistem informasi akuntansi.

Pada hasil analisis regresi linier berganda perngaruh X1 terhadap $Y$, Nilai sig t. 0,000 $\leq 0,05$ mengindikasikan bahwa $\mathrm{H}_{0}$ ditolak dan $\mathrm{H}_{1}$ diterima yang berarti terdapat pengaruh kompetensi sumber daya manusia terhadap efektivitas penggunaan Sistem Keuangan Desa (Siskeudes). Hal ini berarti bahwa semakin tinggi kompetensi sumber daya manusia maka penggunaan aplikasi sistem keuangan desa akan lebih efektif. Organisasi perangkat daerah yang mempunyai sumber daya manusia berkualitas berkualitas, didukung dengan latar belakang pendidikan di bidang akuntansi, mengikuti pendidikan dan pelatihan, serta memiliki pengalaman dibidang tata kelola keuangan keuangan akan dapat mewujudkan pengelolaan keuangan daerah yang baik (Sagara, 2015). Selain itu, Mollanazari (2012) menyatakan bahwa instansi yang memiliki sistem pengendalian internal yang baik yang didukung dengan sistem terkomputerisasi yang digunakan untuk memproses transaksi keuangan dan transaksi nonkeuangan dan sumber daya manusia yang berkualitas sehingga dapat berkoordinasi untuk mendukung dalam pengambilan keputusan yang akan dibuat. Nilai koefisien beta sebesar 0,382 menunjukkan arah positif. Hasil dari penelitian ini serupa dengan penelitian Nintyari et al. (2019) menyatakan bahwa kompetensi sumber daya manusia berpengaruh positif dan signifikan terhadap efektivitas dan efisiensi pelaksanaan Siskeudes. Penelitian Paranoan et al. (2019) juga menemukan bahwa kompetensi sumber daya manusia berpengaruh positif dan signifikan terhadap efektivitas sistem informasi akuntansi.

\section{SIMPULAN}

Kecanggihan teknologi informasi berpengaruh positif terhadap efektivitas Siskeudes. Hasil ini menunjukkan bahwa semakin canggih teknologi informasi yang digunakan oleh perangkat desa atau staff maka semakin efektif penggunaan Sistem Keuangan Desa (Siskeudes). Kompetensi sumber daya manusia berpengaruh positif terhadap efektivitas Siskeudes. Hasil ini menunjukkan bahwa semakin tinggi kompetensi yang dimiliki pegawai maka semakin efektif penggunaan Sistem Keuangan Desa (Siskeudes).

Untuk meningkatkan efektivitas penggunaan Siskeudes, sebaiknya perlu memperhatikan kecanggihan teknologi informasi yang digunakan dan kompetensi sumber daya manusianya. Hal yang dapat diterapkan antara lain dengan memberikan update hardware maupun software yang lebih baru, memberikan alat-alat pendukung teknologi lainnya terutama menyiapkan jaringan internet yang kuat untuk menghindari keterlambatan penginputan data, memberikan sosialisasi atau pelatihan terkait Siskeudes. Dengan demikian maka akan efektivitas penggunaan Siskeudes akan semakin meningkat. Bagi peneliti selanjutnya, diharapkan untuk melakukan penelitian dengan cakupan yang lebih luas seperti melakukan penelitian pada daerah lain, menambahkan variabelvariabel lain diluar penelitian ini, menggunakan teknik analisis data yang berbeda serta mampu menambah referensi terhadap variabel yang akan diteliti. 


\section{REFERENSI}

Abu-Shanab, E., \& Haider, S. (2015). Major factors influencing the adoption of mgovernment in Jordan. Electronic Government, 11(4), 223-240.

Ajzen, I., \& M. Fishbein. (1980). Understanding Attitudes and Predicting Social Behavior. Englewood Cliffs.

Coutu, D. L. (1998). Trust in virtual teams. Harvard Business Review, 76(3), 20-22.

Davis, F. D. (1989). Perceived usefulness, perceived ease of use, and user acceptance of information technology. MIS Quarterly: Management Information Systems, 13(3), 319-339.

Dinas Pemberdayaan Masyarakat dan Desa. (2017). Pedoman Penyusunan Anggaran Pendapatan dan Belanja Desa (APB Desa). Denpasar: Pemerintahan Provinsi Bali.

Emeka-Nwokeji. (2012). Repositioning Accounting Information System Through Effective Data Quality Management: A Framework For Reducing Costs And Improving Performance. International Journal of Scientific \& Technology Research, 1(10).

Fishbein, \& Ajzen. (1975). Belief, Attitude, Intention, and Behavior: An Introduction to Theory and Research.

King, W. R., \& He, J. (2006). A meta-analysis of the technology acceptance model. Information and Management, 43(6), 740-755.

Lisnawati, N. K., Wahyuni, M. A., \& Julianto, P. (2017). Pengaruh Personal Capability, Kecanggihan Teknologi Informasi, Perlindungan Sistem Informasi dan Partisipasi Manajemen Terhadap Efektivitas Sistem Informasi Akuntansi Pada LPD Se-Kecamatan Ubud. In Tahun (Vol. 8).

Miati, N. L. P. M., \& Sutapa, I. N. (2019). Efektivitas Sistem Informasi Akuntansi Dan Pengaruhnya Terhadap Kinerja Karyawan Dengan Teknologi Informasi Sebagai Pemoderasi. JEMA : Journal of Economic, Management and Accounting Adpertisi, 1(1).

Mollanazari, M. (2012). The Effects of Task, Organization and Accounting Information Systems Characteristics on the Accounting Information Systems Performance in Tehran Stock Exchange. International Journal of Innovation, Management and Technology, 3(4).

Nabizadeh, S. M., \& Omrani, S. A. (2014). Effective Factors on Accounting Information System Alignment; a Step towards Organizational Performance Improvement.

Nintyari, L. restiti, Kurniawan, P. S., \& Atmadja, A. T. (2019). Pengaruh Kompetensi Sumber Daya Manusia, Sosialisasi, Serta Manajemen Kontrol Terhadap Efektivitas Dan Efisiensi Pelaksanaan Sistem Keuangan Desa (Siskeudes) (Studi Empiris Pada Desa-Desa Penerima Dana Desa Di Kabupaten Tabanan). In Jurnal Ilmiah Mahasiswa Akuntansi) Universitas Pendidikan Ganesha (Vol. 10).

Paranoan, N., Tandirerung, C. J., \& Paranoan, A. (2019). Pengaruh Pemanfaatan Teknologi Informasi Dan Kompetensi Sumber Daya Manusia Terhadap Efektivitas Sistem Informasi Akuntansi. In Jurnal Akun Nabelo: Jurnal Akuntansi Netral, Akuntabel, Objektif (Vol. 2).

Pradani, N. L. C., Sujana, E., \& Purnamawati, I. G. A. (2017). Pengaruh kecanggihan teknologi informasi, perlindungan sistem informasi, partisipasi manajemen dan pengetahuan manajer akuntansi terhadap efektivitas sistem 
informasi akuntansi pada hotel berbintang di kabupaten karangasem. In JIMAT (Jurnal Ilmiah Mahasiswa Akuntansi) Undiksha (Vol. 7).

Prasetya, I. K. Y. B., Prayudi, M. A., \& Diatmika, I. P. G. (2017). Pengaruh Kompetensi Sumber Daya, Pemahaman, Dan Pengawasan Terhadap Kualitas Sistem Keuangan Desa Di Kabupaten Buleleng. In JIMAT (Jurnal Ilmiah Mahasiswa Akuntansi) Undiksha (Vol. 8).

Pratiwi, D. N., \& Pravasanti, Y. A. (2020). Analisis Penggunaan Siskeudes dalam Pengelolaan Dana Desa. Jurnal Akuntansi Dan Pajak, 20(2).

Puspita, M. K. A. (2018). Pengaruh Kecanggihan Teknologi Informasi, Pemanfaatan Teknologi Informasi, dan Pengetahuan Karyawan Bagian Akuntansi Terhadap Efektifitas Sistem Informasi Akuntansi.

Putri, N. M. K. D., \& Srinadi, N. L. P. (2020). Pengaruh Kecanggihan Teknologi Informasi Dan Kemampuan Teknik Personal Terhadap Efektivitas Penggunaan Sistem Informasi Akuntansi Di Lpd Kecamatan Ubud. Widya Akuntansi Dan Keuangan, 2(1), 1-15.

Rahmawati, D. (2012). Analisis Faktor Faktor yang Berpengaruh Terhadap Pemanfaatan Teknologi Informasi. Jurnal Ekonomi Dan Pendidikan, 5(1).

Robinson Gamar. (2019). Seorang Warga Denpasar Laporkan Dugaan Penyelewengan Dana Desa ke Kejati. Retrieved from https://regional.kompas.com/read/2019/01/21/13445051/seorang-wargadenpasar-laporkan-dugaan-penyelewengan-dana-desa-ke-kejati

Sagara, Y. (2015). The Effect of Implementation Accounting Information System and Competence of Human Resources on the Quality of Financial Reporting. In Research Journal of Finance and Accounting www.iiste.org ISSN (Vol. 6).

Soudani, S. N. (2012). The Usefulness of an Accounting Information System for Effective Organizational Performance. International Journal of Economics and Finance, 4(5).

Utari, N. M., Sulindawati, N. L. G. E., \& Julianto, I. P. (2017). Pengaruh Partisipasi Pemakai Sistem Informasi, Personal Capability, Kecanggihan Teknologi Informasi, dan Peran Pengawas Internal Terhadap Efektivitas Sistem Informasi Akuntansi (Studi Pada Lembaga Perkreditan Desa (LPD) SeKecamatan Banjar). In JIMAT (Jurnal Ilmiah Mahasiswa Akuntansi) Undiksha (Vol. 8).

Wagner, G., Schramm-Klein, H., \& Steinmann, S. (2013). Effects of cross-channel synergies and complementarity in a multichannel e-commerce system - an investigation of the interrelation of e-commerce, m-commerce and IETVcommerce. International Review of Retail, Distribution and Consumer Research, 23(5), 571-581.

Yunianingrum, Y., \& Kolopaking, L. M. (2018). Kemampuan Aparat Pemerintah Desa dan Efektivitas Pengelolaan Keuangan Desa. Jurnal Sains Komunikasi Dan Pengembangan Masyarakat [JSKPM], 2(4), 495-508. 